\title{
Determinants of Output Growth in Africa's Non-Oil Producing Countries (ANOPCs)
}

\author{
E. Oladipo Ogunleye ${ }^{1}$, Oluwaleye Adeniji ${ }^{2 *}$ \\ 1. Department of Economics, Ekiti State University, Ado-Ekiti. Ekiti State, Nigeria \\ 2. Doctoral Student, Department of Economics, Ekiti State University, Ado-Ekiti, Ekiti State, Nigeria \\ *E-Mail of Corresponding author: sambest101@yahoo.co.uk
}

\begin{abstract}
This study examined the determinants of output growth in the 14 selected non-oil producing countries in Africa, using annual time series data spanning from 1980 to 2016 sourced from the World Bank, World Development Indicator (WDI) and IMF International Financial Statistics (IFS). Error-correction based panel cointegration test was employed to test for the panel cointegration between output growth and some selected macro-economic variables. Results revealed that there is a long-term relationship between output growth and the selected macroeconomic variables; that the responses of output growth to the shocks from world oil price are positive and significant in some of the countries which were able to explore alternative sources of energy; that the responses of output growth to the shocks from Federal Fund Rate (FFR) are significant in all the selected countries, among others. Based on the findings, it is recommended that over reliance on oil can be reduced by diversifying into non-oil sources of energy such as natural gas and renewable sources of electricity such as hydro, geothermal, solar and wind. The study also recommends that stable exchange rate policy should be adopted across all African non-oil producing countries as this will go a long way in creating a predictable climate for investment, enhance more proceeds from exports and appreciate domestic currency.

Keywords: : Crude oil, Monetary Policy, Output Growth, Error-Correction Based Panel Cointegration Test and
\end{abstract} African non-oil producing countries(ANOPCs)

DOI: $10.7176 / \mathrm{JESD} / 11-8-15$

Publication date: April $30^{\text {th }} 2020$

\subsection{Introduction}

There is no country in the world either developed or developing that is not concern about what actually determines her output growth. The main question then is why are some countries poor while are others rich and what determines their output growth? Nkurunziza and Bates (2003) noted that economic growth rates are still not high enough to make a real dent in the pervasive poverty and enable developing countries to catch up with other developed nations since investments have remained subdued, limiting efforts to diversify economic structures and boost growth. Mallick and Kumar (2002) specifically noted continued drop in capital formation suggesting that of the components of GDP, investment has been one of the slowest growing, a symptom of looming crisis. Therefore, it is necessary to understand various factors and circumstances that prevail in the African countries which influence their current GDP per capita growth. Consequently, the aim of this study is to investigate the actual determinants and the major driving forces behind the output growth of ANOPCs

Crude oil is arguably one of the most important commodities in today's industrialized economy, as it represents a crucial energy source for many countries. Being a global commodity the effects of crude oil on economies across the world is multifaceted. Virtually all the ANOPCs are predominantly producers of primary products hence many of them depend largely on importation making them import-dependent economies. This is another reason why many of the macroeconomic policies of many countries in the ANOPCs are highly prone to external influences. Therefore to cope with these external influences macroeconomic policies are subject to frequent changes in order to cope with a prevailing situation presented by the external forces at a certain period of time (AFDB 2014).

However, the outlook of monetary policy is reflected in its key variables such as interest rate and money supply. The changes in these two important monetary variables owing to external shocks have important implications on the output growth of the ANOPCs (Afful and Asiedu 2013). 


\subsection{Literature and Empirical Review}

The neoclassical Solow-Swan (1956) economic growth theory, also known as the exogenous growth model, advocates for the accumulation of physical capital as an important driver of economic growth in the short run, while technological advancement is the key determinant of economic growth in the long run. An important extension of the neoclassical growth model was the inclusion of human capital stock as one of the key factors driving economic growth to complement physical capital accumulation

(Mankiw, Romer, and Weil 1992; Islam 1995).

Olawale (2017), investigated the determinants of Economic growth in 18 Sub-Sahara African countries by decomposing Export and Import over the period of 1996-2015 using a neoclassical economic growth model containing GDP, export components, import components, export concentration index, capital and labour force as variables of analysis. The result of fixed effects estimations revealed that both exports and imports contribute significantly to economic growth. His findings also shown that capital formation has a more significant influence on economic growth than labour force. Lumengo B. and Ferdinand (2015) assesses the determinants of economic growth in Sub-Sahara African countries using Ghana as a case study during the period 1970-2012 using the Bayesian Model Averaging (BMA) in order to address the issue of model uncertainty. Making use of the Markov Chain Monte Carlo Model composition (MC)3 for model selections, the results of the empirical analysis show the importance of variables such as current account balance, inflation rate and population growth as well as the role of the dual economy in driving economic growth in Ghana. These results show that economic growth policy in Ghana should not be confined within a specific growth theory, be it neoclassical and Keynesian. The results are robust with the change of model priors in the context of the BMA analysis.

Ndambiri and Ritho. (2012) investigated the determinants of economic growth in the 19 Sub-Sahara African Countries for the years 1982-2000. With the opinion that economic growth is importantly seen as a dynamic phenomenon, their study employs the Generalized Method of Moments (GMM) to explain the factors that determines the growth of economies in the region. The results of the study reveal that physical capital formation, a vibrant export sector and human capital formation significantly contribute to the economic growth among sub-Sahara African countries. However, government expenditure, nominal discount rate and foreign aid significantly lead to negative economic growth. Based on the results of their findings, it is recommended that relevant policies be formulated to promote those sectors that enhance economic growth in the region.

Barro (1999) investigated the determinants of economic growth using an extended neoclassical growth model for 100 countries and covering the period 1960-1995. Based on a panel regression and three stage least squares method, the study results showedthat investment share, growth rate of terms of trade, years of schooling, rule of law index, democracy index and international openness were positively and significantlyassociated with economic growth, while government consumption, total fertility rate, and inflation were negatively and significantly associated with economic growth.

\subsection{Methodology}

\subsection{Theoretical Framework}

Romer (2006) in his modification of Arrow's seminar work on the economies of learning by doing pointed out that investment in knowledge (experience) has strong linkage with increase in productivity. According to him, the indexes of experience by cumulative investment follow the following production function.

$Y_{i t}=F\left(K_{i t}, A(t) L_{i t}\right)$

Where $Y_{i t}$ is the output of country i, $\mathrm{A}(\mathrm{t})$ is the stock of knowledge of country $\mathrm{i}$ at period $\mathrm{t}, K_{i t}$ and $L_{i t}$ are the capital and labour of the country at period t. Romer pointed out that labour is more productive due to accumulation of knowledge which also depends on experience. However experience is a function of past investment. Consequently the growth rate of output can be written as a function of indexes of experience by cumulative investment as follows:

$G(t)=\int_{-\infty}^{t} I(v) d v=K(t)$ 
Where $G(t)$ is the growth rate of the output, $I(v) d v$ is the indexes of the cumulative investment which is equal to capital stock $k(t)$. However, the growth rate of output of the country according to Romer (2006) is equal to the percapita production function (real output or income) i.e

$y=k(t)$

Substituting equation 3 in 2 shows that:

$G(t)=y$

Where $\mathrm{y}$ is the real output

Again, in the definition of money demand function, Romer (1996) postulated a relationship between inflation, money growth and interest rate in such that demand for real money balance is a decreasing function of interest rate and increasing function of real income. That is:

$\frac{M}{P}=L(r, y)$

This can be written in linear form thus:

$\frac{M}{P}=\alpha y-\beta r$

Therefore:

$\alpha y=\frac{M}{P}+\beta r$

Dividing both sides by $\alpha$ leads to:

$y=1 / \alpha\left(\frac{M}{P}\right)+\alpha / \beta(r)$

Where $1 / \alpha$ and $\beta / \alpha$ are elasticities of real money balance and interest rate respectively.

Substituting equation 8 into 4 leads to:

$G(t)=1 / \alpha\left(\frac{M}{P}\right)+\alpha / \beta(r)$

Thus growth rate can be presented as a function of the real money balance and interest rate which determines capital stock investment, where labour remains constant.

Our model is a modification of equation 9. In our attempt to study the determinants of output growth in the economies of ANOPCs, apart from the monetary policy instruments like interest rate and money supply, we also included in the model as explanatory variables some policy variables like exchange rate and inflation rate. All these variables are identified as having direct linkages with monetary policy dynamics (Ngalawa and Viegi, 2012; Omolade and Ngalawa, 2014) While, GDP growth rate is used as a measure of economic growth of the countries and capital formation $\mathrm{K}$ is added as additional control variable because of its important role in growth process.

Again, from the neoclassical perspective of production function the linkages between energy and growth are explained. A general form of production function describes the relationship between oil as a form of energy and economic activity. The function is presented thus;

$\left(Q_{i} \ldots \ldots, Q_{m}\right)=f\left(A, X_{i} \ldots \ldots, X_{n}, E_{i} \ldots \ldots, E_{p}\right)$

Where $Q_{i}$ are various outputs or economic growth

$X_{i}$ are various inputs such as capital, labour among others.

$E_{i}$ are energy inputs used in the production process i.e oil, gas, coal etc.

According to the neo classical economists, the relationship between energy and growth of the GDP gross domestic products can be affected by the following agents

(i) Substitution between energy and other inputs

(ii) Technological change 
(iii) Shifts in the composition of the energy input

(iv) Shifts in the composition of outputs

Other factors can be a shift in the mix of the inputs used in the production; for instance either capital intensity or labour intensity. Basically, the linkage between oil as an input and growth is explained by Mainstream economist through their growth theories with natural resources as a form of energy.

\subsection{Model Specification}

Following equations 9 and 10 our model is expressed thus

$G_{i, t}=\varpi_{0}+\varpi_{j} \sum_{j=2}^{7} \varpi_{j} K_{i, t} \varpi_{j} M_{p i, t}+\varpi_{j} O I L_{p i, t}+\mu_{i, t}$

Where $G_{i, t}$ is the growth rate of output of country $i$ at time $t, M_{p i, t}$ comprises of the monetary policy instruments; real money balance measured by real money supply and real interest rate. It also comprises of policy variables such as real exchange rate, and inflation rate in country $i$ at time $t$, while $K_{i, t}$ is the capital of country $i$ at time $t$ (measured as Gross Capital Formation), $O I L_{p, t}$ is crude oil price at time $t$ and $\mu_{i, t}$ represents the country specific stochastic variable. Note that $i=1,2 \ldots \ldots 14$ and $\mathrm{t}=1,2 \ldots \ldots \ldots, 36$. More explicitly for the panel analysis the model is presented as follows

$g d p g r_{i, t}=\vartheta_{i, t}+\beta_{i, t} i n t r+\alpha_{i, t} m s g r+\theta_{i, t}$ exr $+\delta_{i, t} i n f r+\rho_{, t} o i l+\pi_{i, t}+\mu_{i, t}$.

Where $\quad g d p g r=$ growth rate of Gross Domestic Product, intr $=$ real interest rate, $m s g r=$ growth rate of money supply, exr $=$ exchange rate, infr $=$ inflation and oil $=$ oil price

$\vartheta, \beta, \alpha, \theta, \delta$ and $\delta=$ parameters/coefficients,

The study used quarterly data spanning a period of thirty six years from 1980:Q1 to 2016:Q4 for the economy. The study period is dictated by data availability and an effort to stay current. The data was obtained from the World Development Indicators (WDI) and IMF - International Financial Statistics (IFS).

\subsection{Results and Discussion}

\subsection{Error-Correction Based Panel Cointegration Test}

In this aspect, four basic types of tests are designed for the purpose of testing for panel cointegration. The tests are conducted based on both asymptotic distribution and cross sectional dependence that is, bootstrapping. Results of the asymptotic distribution for the four tests are shown in table 4.1.

Table 4.1: Westerlund Panel Cointegration Test:Asymptotic Distribution Value.

\begin{tabular}{|c|c|c|c|}
\hline Statistic & Value & $Z-$ Value & $\mathrm{p}$-value \\
\hline $\mathrm{Gt}$ & -6.621 & 0.219 & 0.018 \\
\hline $\mathrm{Ga}$ & -3.679 & 6.780 & 1.000 \\
\hline $\mathrm{Pt}$ & -9.643 & 0.432 & 0.024 \\
\hline $\mathrm{Pa}$ & -2.998 & 5.740 & 1.000 \\
\hline
\end{tabular}

Source: Authors' Computation

Each test includes trend and constant terms. The lag and lead lengths are selected based on AICand Barlett Kernel Window. Width is set according to $4[1 / 100] 2 / \mathrm{n}$ which gives approximately 3 in this study.

The results in table 4.1 revealed that two tests out of the four basic tests designed for the purpose of testing for panel cointegration indicates a rejection of the null hypothesis of no long-run relationship between output growth and some selected macro-economic variables. This implies that there is a long-term correlation between output growth and macroeconomic variables in the selected non-oil producing countries in Africa. This study therefore proceeds to estimate the Error Correction Model using the fixed effect within regression. The results are presented in table 4.3 below.

Table 4.2: Fixed Effects (within) Regression Results of GDPgr and some selected macroeconomic variables. 
Long-run Model

\begin{tabular}{|c|c|c|c|}
\hline Variables & \multicolumn{3}{|c|}{ Long - Run Model } \\
\hline GDPgr & Coefficient & Standard Error & Probability \\
\hline EXR & 0.22622 & 0.3614184 & 0.535 \\
\hline FFR & -0.07669 & 0.3158904 & 0.809 \\
\hline GCF & 0.02185 & 0.0760735 & 0.774 \\
\hline INFR & 0.1697015 & 0.1164747 & 0.148 \\
\hline INTR & -0.2897462 & 0.11163 & 0.011 \\
\hline MSGR & 0.0828275 & 0.0375509 & 0.029 \\
\hline WOP & -0.068891 & 0.172832 & 0.691 \\
\hline
\end{tabular}

Short - Run Model

\begin{tabular}{|c|c|c|c|}
\hline DEXR & -0.3691257 & 0.5396225 & 0.495 \\
\hline DFFR & -0.6688541 & 0.356611 & 0.036 \\
\hline DGCF & 0.1908208 & 0.0849789 & 0.027 \\
\hline DINFR & -0.1218408 & 0.888362 & 0.017 \\
\hline DINTR & -0.993143 & 0.632204 & 0.019 \\
\hline DMSGR & 0.342926 & 0.247652 & 0.069 \\
\hline DWOP & -0.999722 & 0.342861 & 0.004 \\
\hline Constant & -1.707141 & 2.746217 & 0.535 \\
\hline Sigma-u & 0.6534298 & & \\
\hline Sigma - e & 1.4544159 & & \\
\hline Rho & 0.03454466 & & \\
\hline
\end{tabular}

Source: Author's Computation

$\mathrm{F}(7,115)=2.51$, Prob $>\mathrm{F}=0.00021, \mathrm{R}$-squared:

Within $=0.2706$, Between $=0.3001,0$ verall $=0.8271$

In a bid to achieve the objective of this study, table above showed the Error-Correction Based Panel Cointegration results using the Fixed Effect Model. The results are into two segments, that is, the long and short-run relationships. The first segment exhibited the variables in their non-differenced forms and this indicating long-run relationship, while the second segment showed the variables in their differenced forms showing the short -run relationships. With respect to the long-run model segment, the empirical results therein indicated that just INTR and MSGR out of all macroeconomic variables examined have significant long-run relationship with the output growth (GDPgr) in the selected non-oil producing countries in Africa during period under review. The results equally revealed that other variables such as EXR, FFR, GCF, INFR and WOP do not have significant impacts on output growth (GDPgr). However, this is quite different in the case of short-runmodel segment in which the results showed that FFR, GCF, INFR, INTR, MSGR and WOP now have significant impacts on output growth (GDPgr). Only EXR does not have significant impact on output growth. The results also revealed that FFR, INFR, INTR and WOP exhibited negative and significant impact on output growth (GDPgr) while GCF and MSGR have positive and significant impact on output growth (GDPgr). This is a strong indication that macroeconomic variables appear to have more significant influence on output growth in the short-run than in the long-run in the selected non-oil producing countries during the period under review. 
The implication of this finding is that macroeconomic variables appear to predict output growth more in the shortrun than in the long-run. The possible reason behind this finding might not be unconnected with the nature of the emerging economies in Africa particularly the non-oil producing countries in Africa where according to Al-Fayomi (2009) as their economies are not fully efficient and therefore do not incorporate all given information to allow long-term co-movement between macroeconomic variables and output growth.

Moreover, the results of both long-run and short-run model segment of the fixed effect regression showed that domestic interest rate has negative and significant impact on output growth in non-oil producing countries in Africa. The implication of this finding is that when interest rate which is the cost of borrowing is high, it will lead to disincentive in borrowing; which will eventually discourage investment and thus a declining output growth rate. This finding aligns with the work of Irfan and Ume (2011) and HameedGul et al (2012). Also, the results of both long-run and short-run model segment of the fixed effect regression revealed that Money supply growth rate (MSGR) exerted positive and significant impacts on output growth in non-oil producing countries in Africa. This finding conforms with the economic theory stating that money supply is an increasing function of economic growth, which means that as money supply increases, output growth also increases. This finding also agrees with the works of Ahmad and Suleiman (2011) and Mishra (2012) who posited in their research works that expansionary monetary policy through increase in money supply is a declining function of interest rate which eventually triggers investment and leads to output growth increment.

In addition, the results from the short-run model segment of the fixed effect regression exhibited that Gross Capital Formation (GCF) has positive and significant impact on output growth in non-oil producing countries in Africa. This particular finding indicates that there can be no significant output growth without investments in fixed and productive capital. This finding also corroborates the assertions of Adjasi and Biekpe (2009) and Gutierrez (2005) who posited that private capital increases in productive areas, output growth will equally be increased.

The results of the cross-sectional dependence test which is based on the correlation matrix of the residual and Breusch-pagan LM test of independence are presented in table 4.3 below

Table 4.3: Correlation Matrix of Residuals

\begin{tabular}{|l|l|l|l|l|l|l|l|l|}
\hline & $\mathrm{e}_{1}$ & $\mathrm{e}_{2}$ & $\mathrm{e}_{3}$ & $\mathrm{e}_{4}$ & $\mathrm{e}_{5}$ & $\mathrm{e}_{6}$ & $\mathrm{e}_{7}$ & $\mathrm{e}_{8}$ \\
\hline $\mathrm{e}_{1}$ & 1.0000 & & & & & & & \\
\hline $\mathrm{e}_{2}$ & -0.1472 & 1.0000 & & & & & & \\
\hline $\mathrm{e}_{3}$ & 0.3146 & 0.0691 & 1.0000 & & & & & \\
\hline $\mathrm{e}_{4}$ & -0.0121 & -0.4179 & -0.0394 & 1.0000 & & & & \\
\hline $\mathrm{e}_{5}$ & -0.4126 & -0.5217 & 0.6871 & 0.3412 & 1.0000 & & & \\
\hline $\mathrm{e}_{6}$ & 0.0216 & 0.0219 & 0.0248 & 0.0814 & 0.4371 & 1.0000 & & \\
\hline $\mathrm{e}_{7}$ & -0.0317 & 0.6215 & 0.0198 & -0.6127 & -0.0124 & 0.3879 & 1.0000 & \\
\hline $\mathrm{e}_{8}$ & 0.1497 & 0.1762 & 0.7257 & 0.3272 & 0.8427 & -0.4214 & 0.0614 & 1.0000 \\
\hline
\end{tabular}

Source: Author's computation

Breusch-Pagan LM test of independence: Chi2 (36) = 151.418

$\operatorname{Pr}=0.0005, \mathrm{H} 0$ : There is no cross-sectional dependence

The table above presented the results of the cross-sectional dependence test. From the results, the null hypothesis of no presence of cross-sectional dependence is rejected as the probability value $(0.0005)$ is less than $1 \%$ level of significance. This result therefore indicates that non-oil producing countries in Africa respond differently to their common factor shocks. In this regard, the presence of cross-sectional dependence in this research work justifies the testing for bootstrapping option as a means of getting a robust $\mathrm{p}$-value even in the presence of cross-sectional dependence.

\subsection{Structural Vector Autoregressive (S-VAR) Model}

The presence of cross-sectional dependence in the Correlation Matrix of residual tests conducted which necessitates the use of alternative estimation technique to examine the responses of the selected non-oil producing countries to their common factors separately. The reason behind this is that cross-sectional dependence is majorly caused by the presence of common factors among the units, thereby leading to cross-member correlation. For instance, non-oil producing countries in Africa are known to have common characteristic of being emerging and 
dependent economy. This gives room for the tendency of sharing similar factors among themselves. However, the responses of these African countries to the common factor shocks might be at varying degrees due to different social norms, economic effects and independent preferences that characterize each of the African countries (Pesaran, 2013). Structural Vector Autoregressive (S-VAR) is therefore employed to examine how each non-oil producing country in Africa responds differently to their common factor shocks.

\subsubsection{Structural VAR: Impulse Response Function and Variance Decomposition.}

Impulse Response function assesses the effect of one standard deviation shock in an exogenous variable to one of the innovations of the endogenous variable of a model within a given period of time. In other words, it is used to predict or forecast the response of each endogenous variable to a standard deviation change in all other exogeneous variables. Moreover, variance decomposition examines the proportion of variation of the dependent variable explained by each of the independent variables. It shows which of the independent variable is stronger in explaining the variability in the dependent variables over time. Both S-VAR Impulse Response Functions and Variance Decompositions are shown in the figures and table below respectively.

Figure 1a: Response of Output Growth (GDPgr) to World Oil Price (WOP) shock in the selected Non-oil producing countries in Africa.

Response of GDPgr to WOP SENEGAL

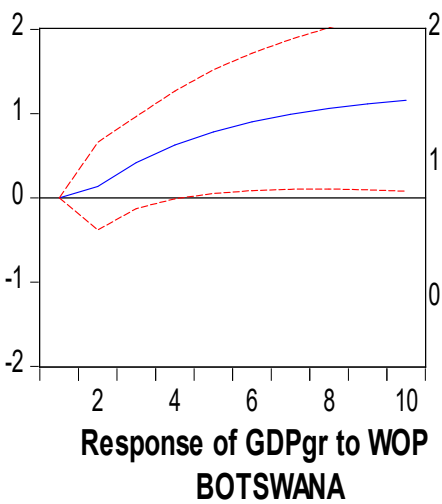

BOTSWANA

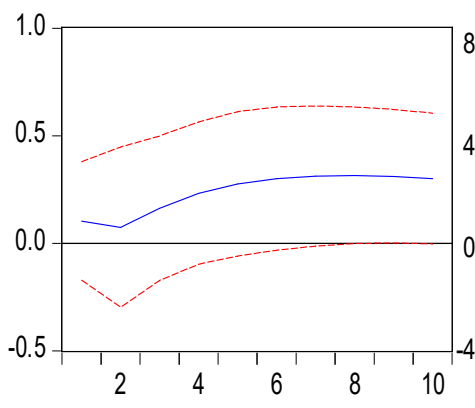

Response of GDPgr to WOP UGANDA

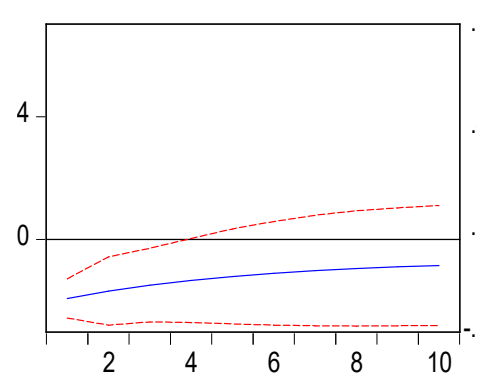

Response of GDPgr to WOP KENYA

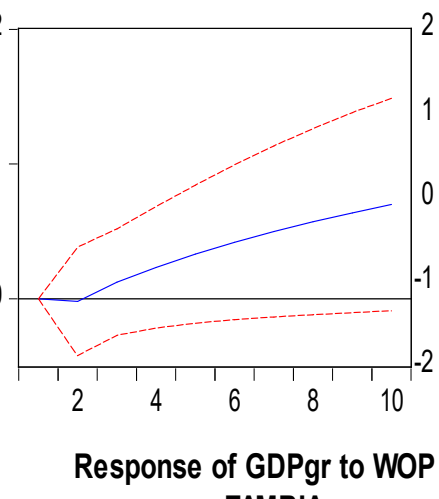

ZAMBIA

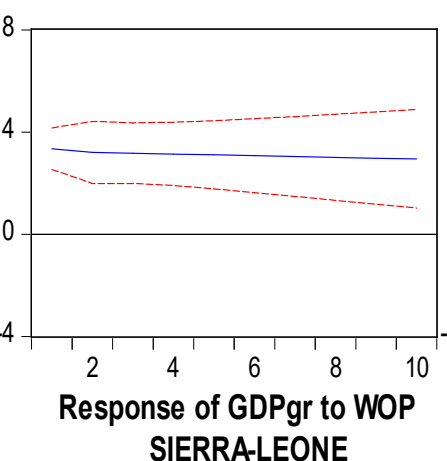

SIERRALEONE
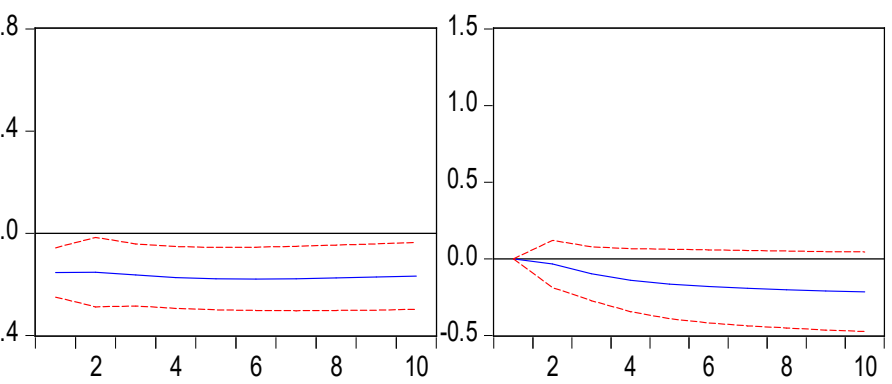
Table 4.4: Variance Decomposition of Output Growth (GDPgr) with respect to World Oil Price (WOP) shock in the selected Non-oil producing countries in Africa.

\begin{tabular}{|c|c|c|c|c|c|c|c|c|c|c|c|c|c|c|}
\hline . & $\stackrel{\varphi}{\dot{\varphi}}$ & 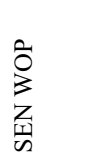 & $\sum_{i}^{\sharp}$ & $\begin{array}{ll}\sum_{1} & 0 \\
3 & 3\end{array}$ & $\begin{array}{l}\hat{0} \\
3 \\
0 \\
0 \\
0 \\
0 \\
0\end{array}$ & $\begin{array}{l}\stackrel{0}{0} \\
\sum \\
\sum \\
\sum\end{array}$ & 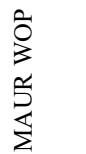 & 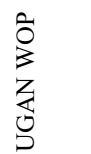 & 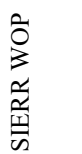 & $\begin{array}{l}\hat{O} \\
z \\
z \\
z \\
z\end{array}$ & $\begin{array}{l}0 \\
0 \\
0 \\
0 \\
0 \\
0\end{array}$ & $\begin{array}{l}0 \\
\sum_{0}^{\infty} \\
\sum\end{array}$ & $\begin{array}{l}0 \\
0 \\
\sum \\
\sum \\
z\end{array}$ & 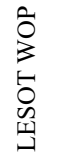 \\
\hline 3 & 11.25147 & 15.20197 & 10.30217 & 31.41271 & 12.67981 & 20.73141 & 15.92141 & 50.14211 & 10.41767 & 45.41411 & 30.71412 & 25.3917 & 45.3141 & 51.4141 \\
\hline 6 & 12.30216 & 25.81613 & 20.50316 & 45.51211 & 14.03141 & 35.10711 & 11.21098 & 35.31141 & 17.31498 & 15.71421 & 21.31410 & 15.41310 & 30.12141 & 42.31141 \\
\hline 9 & 12.62107 & 45.52108 & 30.79812 & 58.10213 & 20.71431 & 40.79811 & 9.01417 & 21.41278 & 3.40914 & 7.47911 & 10.71410 & 11.41025 & 21.3241 & 30.14147 \\
\hline 12 & 13.81432 & 60.21710 & 40.32178 & 64.70161 & 41.81403 & 53.41211 & 3.14218 & 11.3410 & 1.89418 & 3.98104 & 4.32017 & 8.41025 & 10.1414 & 11.32178 \\
\hline
\end{tabular}

Figure 1a displayed the response of output growth to (WOP) in each of the selected non-oil producing countries in Africa. Likewise in order to complement the result of Impulse Response function in Figure 1a, table 4.4 showed the Variance Decomposition of GDPgr with respect to WOP in the selected non-oil producing countries in Africa. Result from figure 4.1a revealed that the response of output growth (GDPgr) to a standard deviation shock from (WOP) is positive and significant in Senegal,Kenya, Swaziland, Botswana and Zambia. Shock from WOP produced similar effect on GDPgr in Senegal and Swaziland as the shock from WOP was huge on GDPgr at the initial stage but later tended to diverge towards equilibrium as time increases. This result was supported by the result of variance decomposition depicted in table 4.2a in which the WOP shock in both Senegal and Swaziland explained about $15 \%$ and $31 \%$ of the variation in GDPgr in third quarter respectively, but the proportionate explanation power increased significantly as the quarter progresses to about $60 \%$ and $64 \%$ respectively in the $12^{\text {th }}$ quarter. Also, the positive impact of the shock from WOP on GDPgr was largely significant and even exploded as time increases in Kenya, Botswana and Zambia. These results equally align with the results of variance decomposition shown in table 4.2a in which the WOP shock explained about $10 \%, 12 \%$ and $20 \%$ variance in GDPgr in quarter 3 in Kenya, Botwsana and Zambia respectively. But the innovative power increased rapidly and significantly to about $4 \%, 41 \%$ and $53 \%$ in the $12^{\text {th }}$ quarter in these countries respectively.

Meanwhile, findings from both S-VAR Impulse Response Function and Variance Decomposition produced results that actually contradict theoretical expectation as the standard deviation shock from WOP exerted positive and significant impact on the output growth in Senegal, Kenya, Swaziland, Botswana and Zambia. The outcome of these results might be linked to the fact that these countries might have identified and explored alternative sources of energy that helped them to adopt measures to reduce the level of dependency on oil in international market. This might have gone a long way in protecting these countries from the negative impacts of World Oil Price increase. Example of this fact can be seen in Senegal, Kenya and Swaziland who have implemented various Biofuels production initiatives over the past few years to improve their energy sectors. Through these initiatives, several Biofuels projects were carried out in these countries with the inclusion of the plantation of Jatropha oil seeds which were grown on thousand hectares of land in these countries (Mitchell, 2011)

Table 4.5: Variance Decomposition of Output Growth (GDPgr) with respect to Federal Fund Rate (FFR) shock in the selected non-oil producing countries in Africa.

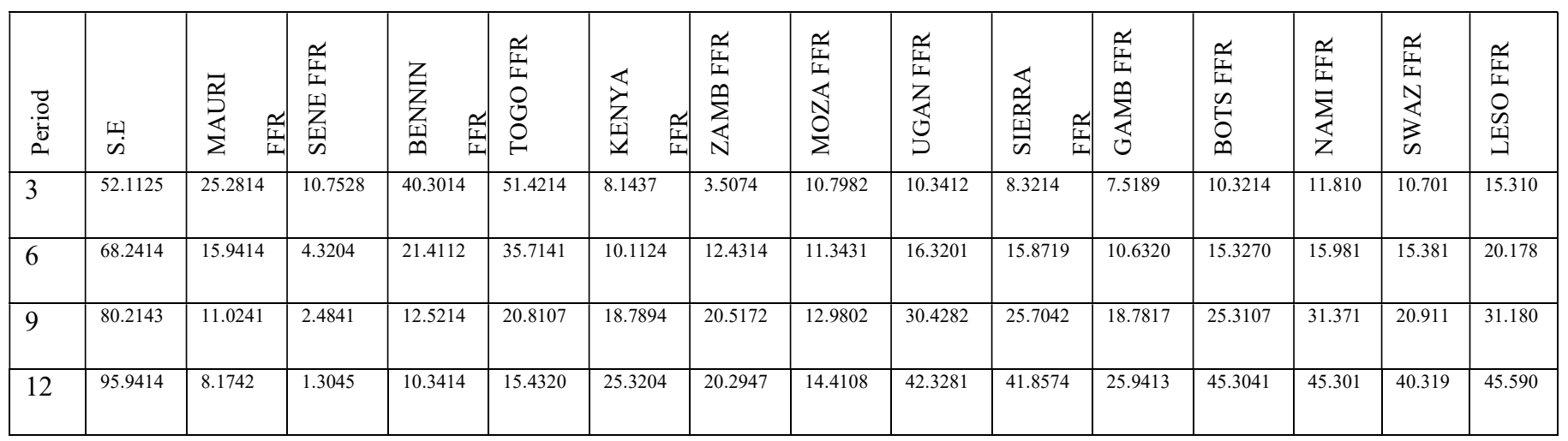


Figure 1b: Response of output growth (GDPgr) to Federal Fund Rate (FFR) shock in the selected non-oil producing countries in Africa.
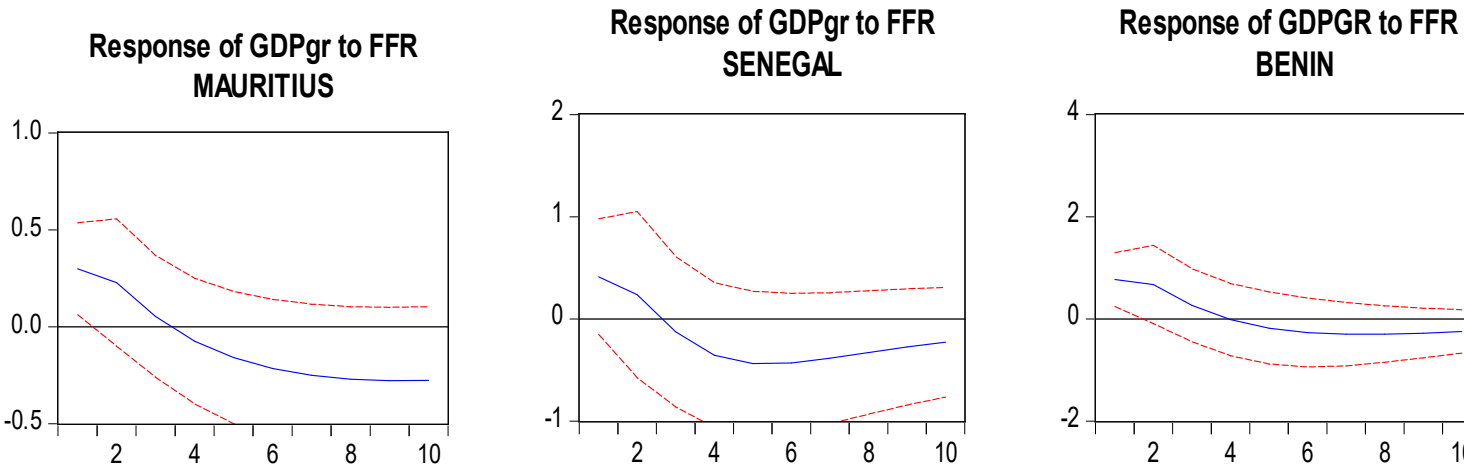

Response of GDPgr to FFR TOGO

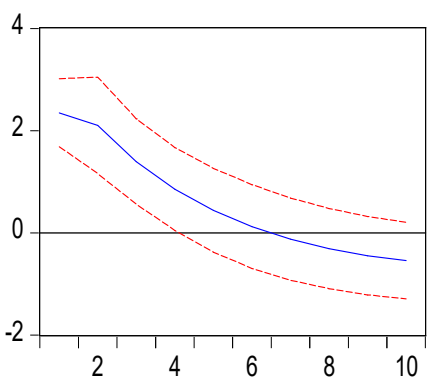

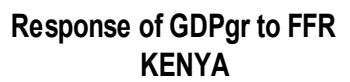

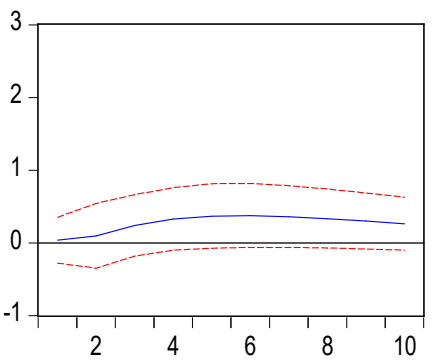

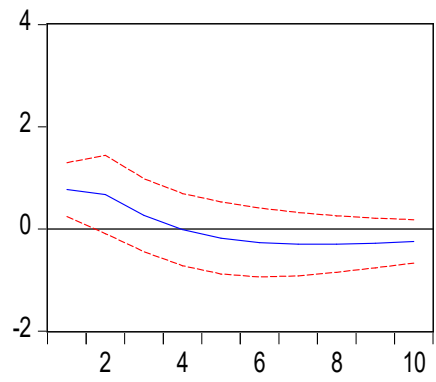

Response of GDPgr to FFR ZAMBIA

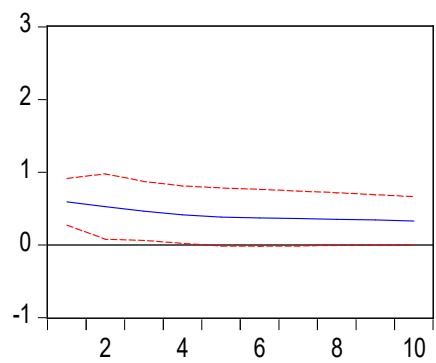

Response of GDPgr to FFR

Response of GDPgr to FFR MOZAMBIQUE

Response of GDPgr to FFR SIERRA-LEONE

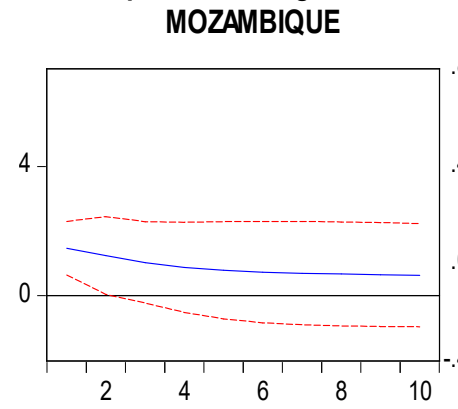
UGANDA

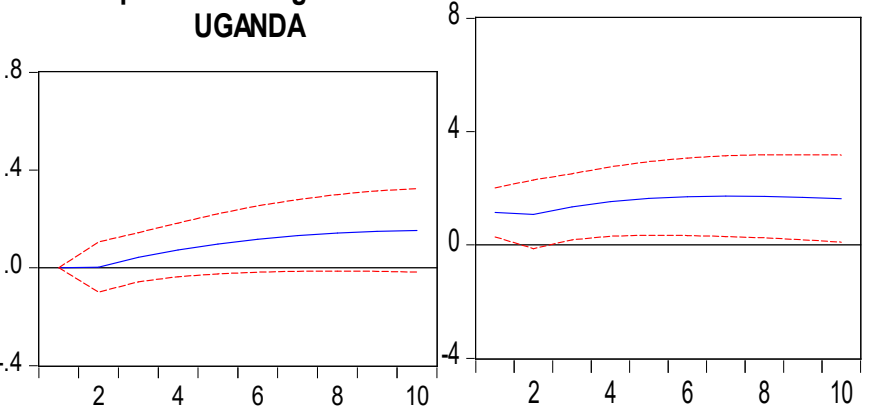

Figure $1 \mathrm{~b}$ exhibited the response of output growth (GDPgr) to Federal Fund Rate (FFR) shock in the selected nonoil producing countries in Africa. Also, in a bid to support the results of Impulse Response Function in figure 1b, Table 4.5 exhibited the Variance Decomposition of GDPgr with respect to FFR in the selected non-oil producing countries in Africa. The results from figure $1 \mathrm{~b}$ revealed that the response of GDPgr to a shock from FFR was positive initially, diverged toward equilibrium in the $3.8^{\text {th }}, 3^{\text {rd }}, 4^{\text {th }}$ and $6^{\text {th }}$ period and eventually fell to the negative axis in Mauritius, Senegal, Bennin snd Togo respectively. This result is consistent with the results of Variance Decomposition in Table 4.2b in which the shock from FFR explained about 25\%, 10\%, 40\% and 50\% variance in GDPgr during the $3^{\text {rd }}$ quarter in Mauritius, Senegal, Benin and Togo respectively, but the proportionate explanation power decreased significantly to about $8 \%, 1 \%, 10 \%$ and $15 \%$ in those countries respectively during the $12^{\text {th }}$ quarter. In addition, figure $4.1 \mathrm{~b}$ equally revealed that a standard deviation shock coming from FFR exerted positive and significant impact on GDPgr in Kenya, Zambia, Mozambique, Uganda, Sierra-Leone, Gambia, Botswana, Namibia, Swaziland and Lesotho. But these positive and significant impacts are mostly pronounced in Swaziland and Lesotho during the period under review. The result of this Impulse Response Function agreed with the result of Variance Decomposition in table $4.2 \mathrm{~b}$ in which the FFR shock explained about $8 \%, 3 \%, 10 \%, 10 \%, 8 \%, 7 \%$, 
$10 \%, 11 \%, 10 \%$ and $15 \%$ variation in GDPgr during the $3^{\text {rd }}$ quarter in Kenya, Zambia, Mozambique, Uganda, Sierra-Leone, Gambia, Botswana, Namibia, Swaziland and Lesotho respectively. But the proportionate explanation power of FFR shock increased significantly as the quarter progresses to $25 \%, 30 \%, 14 \%, 42 \%, 41 \%$, $25 \%, 45 \%, 45 \%, 40 \%$ and $45 \%$ in those countries respectively in the $12^{\text {th }}$ quarter.

\subsection{Conclusion and Recommendations}

This study examined the determinants of output growth in the selected non-oil producing countries in Africa. Results from the study revealed that the response of output growth to the shocks from world oil price are positive and significant in some African non-oil producing countries who were able to explore alternative sources of energy. Findings from the study also revealed that the responses of output growth to the shocks from Federal Fund Rate (FFR) are significant in all the selected African non-oil producing countries. Based on this finding, this study therefore concludes that the economies of African non-oil producing countries are exposed and sensitive to the US Federal Fund Rate which represents the foreign interest rate.

Based on this finding, this study concludes that adoption of stable exchange rate is sufficient enough to shield the economies of African non-oil producing countries from the negative effects of an increase in the global oil price. Therefore, this study concludes that expansionary monetary policy through reduction in interest rate to enhance investment is more effective in compensating and offsetting the negative effects of an increase in the global oil price in the selected African non-oil producing countries. Based on the findings of this study, the following recommendations were raised: over reliance on oil can be reduced by diversifying into non-oil sources of energy. The most common alternative are natural gas and renewable sources of electricity such as hydro, geothermal, solar and wind. Biofuels have also been adjudged to be common substitute for liquid transportation fuels. A high response and sensitivity of output growth in the African non-oil producing countries to the US Federal Fund Rate which represents foreign interest rate is a signal to the government, policy analysts, investors and Central Bank of non-oil producing countries in Africa that U.S monetary policy shocks should be properly monitored. Government of non-oil producing countries in Africa should try and tighten fiscal policy in the face of rising capital inflows as this will dampen spending, put downward pressure on domestic interest and stimulate investment and output growth. Stable exchange rate policy should be adopted across all African non-oil producing countries as this will go a long way in creating a predictable climate for investment, enhance more proceeds from exports and appreciate domestic currency. This will be capable enough to mitigate the negative impacts of high global oil price. Finally, effective expansionary monetary policy, through reduction in the interest rate should be adopted by all African non-oil producing countries.

\section{References}

Adjasi, C. K. D. \& Biekpe, N. (2009). "Do stock markets matter in investment growth in Africa"? The Journal of Developing Areas, 43 (1), 109-120.

Al-Fayoumi, A.N., (2009). "Oil prices and stock market returns in oil importing countries: The case of Turkey, Tunisia and Jordan”, European Journal of Economics, Finance and Administrative Sciences 16, 86-101.

Ana and Elena [2007]. "Oil Price Shocks, Systematic Monetary Policy and the "Great Moderation", published by the Department of Economics, Michagan State University, 110 Marshall-Adams Hall, East Lansing

Asongu, S. A. (2014). "A note on the longrun neutrality of monetary policy", New empirics. European Economics Letters, 3, (1), 1-6.

Berument, H. (2009). "Measuring monetary policy for a small open economy", Turkey, Journal of Macroeconomics 29,(7), 411-430.

Bolinger, M., Wiser, R., Golove W. [2002], "Quantifying the Value that Wind Power Provides as a Hedge against Volatile Natural Gas Prices", Lawrence Berkeley National Laboratory.

Ciner, C. [2001], "Energy shocks and Financial Markets: Nonlinear Linkages, Studies in Nonlinear Dynamics and Econometrics", October, 5 (3), 203-212

Cologni, A. and Manera, M. (2008). "Oil Prices, Inflation and Interest Rates in a Structural Cointegrated VAR Model for the G-7 Countries", Energy Economics, Vol. 30, No.3, pp. 8569-888.

Cunado, J., Gracia. F. P. D., (2005). "Oil Prices, economic activity and inflation: Evidence for some Asian countries". Quarterly Review of Economics and Finance 45,65-83

Dollar, D. (1992). "Outward-Oriented Developing Economies Really do Grow more rapidly: Evidence form 95 LDCs",

Ferderer, J. P. [1996], “Oil Price Volatility and the Macroeconomy”, Journal of Macroeconomics 18 1, Winter, $1-26$ 
Fischer, S. (1992). "Macroeconomic Stability and Growth". Cuadernos de Economia 29 (87): 171-186.

Hamilton, J. D. [1983] “Oil and the Macroeconomy since World War II”,Journal of Political Economy 91 (2), $228-248$

Hamilton, J.D. [1996], “This is what happened to the oil price-macroeconomy relationship", Journal of Monetary Economics 38, 215-220

Hegerty, S. W. (2010). "Exchange-market pressure and currency crises in Latin America":Empirical tests of their macroeconomic determinants. Economics Bulletin, 30, 2210-2219.

Irfan, H. \& Ume, A. (2011). "Impact of monetary policy on Gross Domestic Product (GDP) of Pakistan”.Interdisciplinary Journal of Contemporary Research in Business, 3(1), 1348-1361.

International Monetary Fund. (2006). "International Financial Statistics” Washington, DC: IMF.

International Financial Statistics (IFS) (2015). Washington DC: International Monetary Fund.

Jimenez-Rodriguez R. and Sanchez, M. (2005). "Oil Shocks and Real GDP Growth": Empirical Evidence from OECD Countries. Applied Economies Vol.37, pp210-228.

Jones, C.M.; Kaul, G. [1996], "Oil and the Stock Markets”, The Journal of Finance, Vol LI, No. 2

Kesicki F. [2009]. "The third oil price surge - What is different this time and what are possible future oil price developments"? Institute of Energy Economics and the Rational Use of Energy, Working Paper

Loungani, P. [1986], “Oil price shocks and the dispersion hypothesis”. Rev. Econ. Stat. 68 3, 536-539.

Mallick, S. K. \& Kumar, T. K. (2002). "Determinants of Long-term Growth inIndia: A Keynesian Approach, Progress in Development Studies", 2 (4), October 2002, 306-324.

Lumengo B. and Ferdinand A. (2015). "Determinants of Economic Growth in Sub-Saharan Africa: The case of Ghana" Department of Economic and Econometrics, University of Johannesburg, South Africa

Mankiw, N. G., Romer, D., and Weil, D. N. (1992) "A Contribution to the Empirics of Economic Growth". Quarterly Journal of Economics 107 (2): 407-437.

Mishra, P.(2012). "How effective is monetary transmission in low-income countries"? A survey of the empirical evidence.Economic Systems, 37 (2), 187 - 216.

Mitchell, D. (2011). "Biofuels in Africa: Opportunities, Prospects, and Challenges" the World Bank Report; The International Bank for Reconstruction and Development: Washington, DC, USA, 2011.

Mork, K.A., Olsen, O. and Mysen, H.T. [1994], "Macroeconomic responses to oil price increases and decreases in seven OECD countries". Energy Journal 15 4, 19-35.

Mork, K (1989), "Oil and the Macro economy, When Prices Go Up and Down: An Extension of Hamilton's Results", Journal of Political Economy, vol. 97, No. 51

Most, S. J., and Vann de Berg, H. (1996). "Growth in Africa: Does the source of investment financing matter”? Applied

Mundell, R. A. (1963). "Capital mobility and stabilization policy under fixed and flexible exchange rates", The Canadian Journal of Economics and Political Science / Revue Canadienne d'Economique et de Science Politique ol.29, no.4, pp475-485.

Ndambiri H.K and Ritho C. (2012). "Determinants of Economic Growth in Sub-saharan Africa: A Panel Data Approach" International Journal of Economics and Management Sciences Vol. 2, pp. 18-24

Ngalawa, H., \& Viegi, N. (2011). "Dynamic effects of monetary policy shocks in Malawi” South African Journal of Economics, 79, (3), 244-250.

Nkurunziza, J. D. \& Bates R. H. (2004). "Political Institutions and Economic Growth in Africa".Center for International Development Working Paper, No. 98.Harvard University.

Olawale .O, (2017) "Determinants Of Economic Growth In Sub-Saharan Africa: Decomposition of Exports And Imports" The Graduate School of Business University of Cape Town

Omolade, A., \& Ngalawa, H. (2014). "Oil revenue and manufacturing sector growth in Africa's oil-exporting countries". Journal of Economic and Financial Sciences, 7(3), 925-944.

Papapetrou, E. [2001], "Oil price shocks, stock market, economic activity and employment in Greece”, Energy Economics Vol. 23 (5) September, 511-532. European Monetary Union", Journal of Economic Studies, Vol. 26 Issue: 4/5, pp.338-382,

Rael Adhiambo Onyango (2015) International Journal of Economic, Commerce and Management, United Kingdom, Vol. III, Issue 11, November 2015

Raguindin.E., and Reyes, R.G. (2005). "The effects of oil price shocks on the Philippine economy: a VAR approach" Working Paper, University of the Philippines School of Economics.

Rebeca and Marcelo [2003]. "Oil Price Shocks and Real GDP Growth: Empirical Evidence for Some OECD Countries", European Central Bank Working Paper No. 36266

Romer, P. M. (2006), “Increasing Returns and Long-Run Growth”, Journal of Political Economy 94 
Senn, (1999) "Monetary policy and the definition of money: Implications for the European Monetary Union", Journal of Economic Studies, Vol. 26 Issue: 4/5, pp.338-382,

Solow, R.M. (1956). "A Contribution to the Theory of Economic Growth". Oxford Review of Economic Policy 23 (1): 3-14.

Wang, S.Q., and Chen, Y. (2009).“Analysis of the Impacts of Emergencies on International Oil Price,” Mathmatics in Practice and Theory, Vol. 9, p. 88.

Wakeford, J J. (2006). "Risks to Global Trade and Implications for South Africa's Economy and Policy". DPRU Working Paper No. 06/111. July 2006. Development Policy Research Unit, University of Cape Town.

Yan, [2012], "Analysis of the International Oil Price Fluctuations and Its Influencing Factors". American Journal of Industrial and Business Management, 2012, 2, 39-46

Yang, C.W.; Hwang, M.J.; Huang, B.N. [2002], "Ananalysis of factors affecting price volatility of the US oil market", Energy Economics 24, 107-119

Zhang, D. (2008). “Oil shock and economic growth in Japan: A nonlinear approach”. Energy Economics, 30, 2374 $-2390$ 